\title{
A charophyte flora from the Lower Pechelbronn Formation (?Upper Eocene/?Lower Oligocene) of Malsch south of Heidelberg (SW Germany)
}

\author{
J. SCHWARZ' \& Th. W. GRIESSEMER ${ }^{2}$ \\ ${ }^{1}$ Habsburgerallee 104, D-60385 Frankfurt, Germany. \\ ${ }^{2}$ Robert-Schumann-straße 61, D-67105 Schifferstadt, Germany.
}

\begin{abstract}
The Lower Pechelbronn Formation (?Upper Eocene/?Lower Oligocene) of Malsch (clay-pit 'Am Viehweg') yielded a moderately abundant charophyte assemblage. One new species, Chara rhenana sp. nov., is erected, two more species, Harrisichara lineata and Nitellopsis (Tectochara) cf. wonnacotti, are recorded in the Rhine Graben area for the first time. The Lower Pechelbronn Formation may be correlated to the Stephanochara vectensis zone (Riveline, 1986) and the mammalian level MP 20 (reference locality: St. Capraise; Schmidt-Kittler, 1987). The associated ostracod fauna clearly indicates a limnic depositional environment. J. Micropalaeontol. 13(2): 147-156, December 1994.
\end{abstract}

\section{INTRODUCTION}

The Palaeogene block of Malsch is situated between the Tertiary sediments covered by mighty Quaternary deposits of the Rhine Graben to the west and the Mesozoic sediments of the Kraichgau to the east (Barth, 1970a), about $20 \mathrm{~km}$ south of Heidelberg (Fig. 1). This uplifted block, whose structure had been recognized for the first time by Moos (1934)-Roter Septarientonplatte - is built up by Palaeogene sediments (Eocene Basal Clay, Lymnaea Marls, Pechelbronn Formation, Grey Marls Formation) with an overall thickness of $460 \mathrm{~m}$ maximum.

At the southern edge of this block, very close to the eastern peripheral fault of the Rhine Graben, several clay-pits are situated; in this area Lymnaea Marls and the Pechelbronn Formation are exposed at the surface. The first clay-pits had been laid out at the beginning of this century east of Federal Highway 3 (Heidelberg-Karlsruhe); these are currently refilled (clay-pits 'Guggen' and 'Dittmannstal'; Barth, 1970b). The latter was of particular interest for mammalian palaeontology since a well-dated fauna from the Lower Pechelbronn Formation had been described by Tobien $(1949,1968,1987,1988)$. West of Federal Highway 3 are located the clay-pits 'Reimschloch' and 'Am Viehweg'.

The first indication of an occurrence of charophytes in the clay-pits of Rot-Malsch was given by Wilser (1922). She cited Chara petrolei from strata of the clay-pit 'Guggen', erroneously assumed by her to be Cyrena Marls; this charophyte species, however, may not be interpreted with certainty (Schwarz \& Griessemer, 1992).

The only further information referring to the subject is Barth (pers. comm.) who succeeded in isolating gyrogonites from samples of the clay-pits 'Reimschloch' and 'Am Viehweg'; these specimens were later determined by Dr K. Mädler (Hanover).

\section{SAMPLING}

The material for this paper was obtained from 15 samples taken by one of us (Th.G.) in 1988 from the clay-pit 'Am
Viehweg', excavated by the 'Ziegelwerke Bott-Eder GmbH' at Rauenberg. Due to the clay-extracting methods using a bulldozer, no detailed collecting could be carried out. Detailed collecting was carried out by Barth in the 1960s, however, when clay was extracted by bucket chain excavating.

\section{GEOLOGY}

The clay-pit 'Am Viehweg', origin of the charophytes subsequently described, has been exploited since 1962 . The sediments, exposed at present, nearly $125 \mathrm{~m}$ in thicknesss, are exclusively of ?Upper Eocene/?Lower Oligocene age. According to Barth (1970a: fig. 2) the strike angle varies between $55^{\circ}$ and $85^{\circ}$, and the dip angle between $22^{\circ}$ and $40^{\circ}$ to the NW. Thus, the age of the sediments decreases from SE (samples 1-3c) to NW (sample 13). The sampled sediments predominantly belong to the Lower Pechelbronn Formation, consisting of muds and calcareous muds with intercalated sandstones; only sample 13 may belong already to the overlying Middle Pechelbronn Formation, normally containing a rich ostracod and foraminiferal fauna.

The collected samples show olive-green to grey colours (1-3c, 7-12), while samples 4-6 came from red to 'beige'-coloured muds. At the NE edge of the pit, close to the ' $g$ ' of 'Viehweg' on the map (Fig. 1c), intense reddish-coloured muds with alabaster gypsum nodules can be observed. The stratigraphical position of these intensecoloured muds has not yet been clarified. There are indications that they may represent a special local type of facies somewhere within the sequence of the Lower Pechelbronn Formation. Alternatively, the aforementioned petrographic characters also allows one to regard them as the 'Rote Leitschicht'. This is a very important marker-level encountered by petroleum geologists in many borings in different oilfields in the middle part of the Rhine Graben. The 'Rote Leitschicht' is considered to be a separate stratigraphical unit underlying the Lower Pechelbronn 


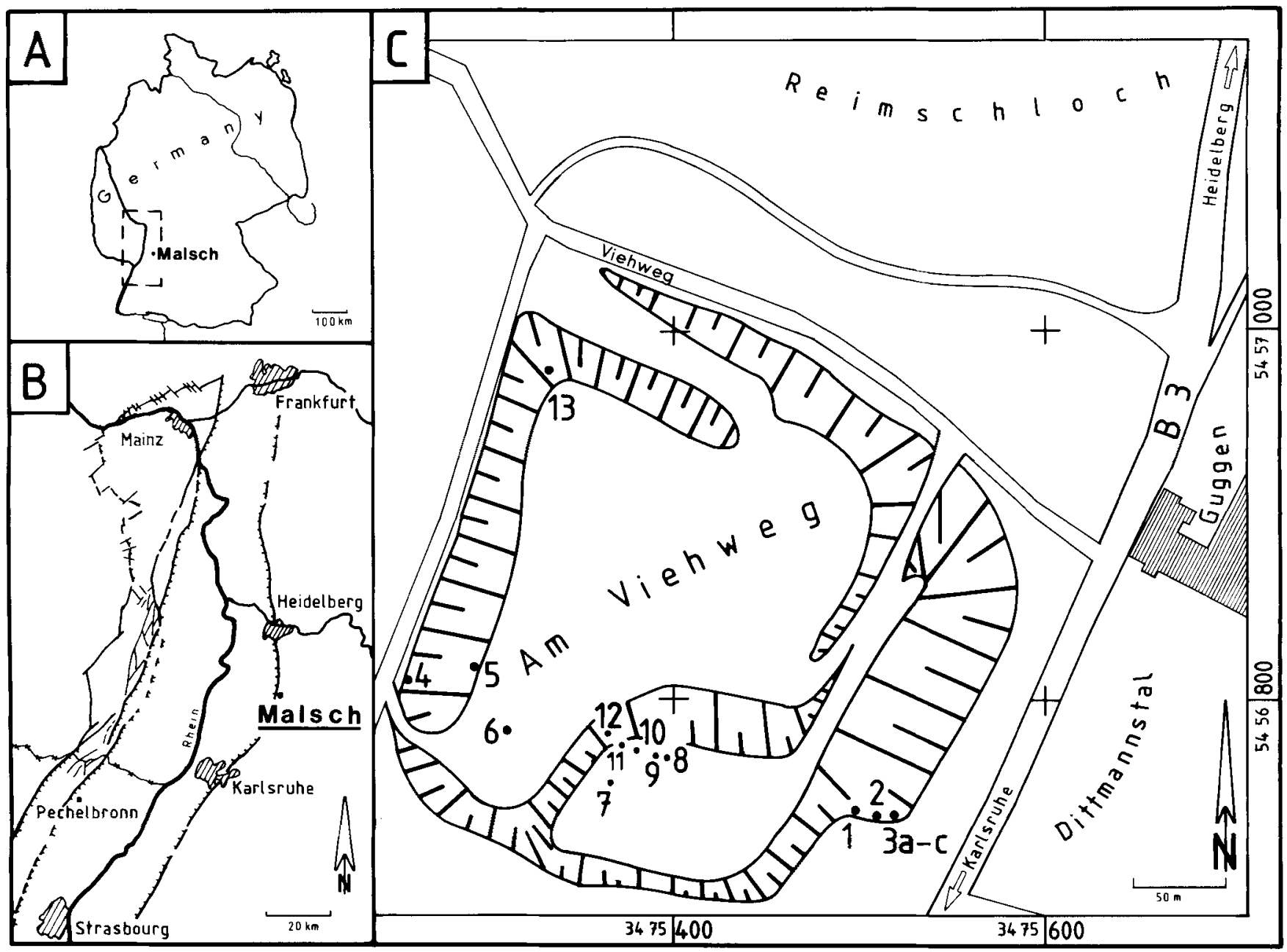

Fig. 1. Geographical position of the clay-pit 'Am Viehweg' (C) within the middle part of the Rhine Graben (A, B). The numbers refer to the samples taken.

Formation by some authors. Other geologists include it in the Lower Pechelbronn Formation, to represent the basal part of it, an opinion the authors of this paper would share.

\section{MICROFAUNA}

Besides the charophyte species, our knowledge about the palaeoecological demands of the accompanying microfauna is essential to the interpretation of the palaeoenvironment. Nearly all samples yielded a freshwater ostracod fauna, preserved in most cases with broken valves. The valves and fragments could be assigned to the following genera: Heterocypris?, Herpetocypris?, Ilyocypris, Paralimnocythere, Stenocypris and Virgatocypris. These genera are known to inhabit freshwater, salinity being less than $\mathbf{3} \%$. Stenocypris is regarded as a genus living in warm waters (Morkhoven, 1963: 55; Triebel, 1953: 12). Thus the whole fauna can be attached to the Candona-Cypridopsis assemblage (Keen, 1975), which lived in shallow lakes or lake edges. In addition, some internal moulds of snails have been found by picking the samples. The other fauna (Jurassic ostracodes, sclerites of sponges, columnalia of crinoids, spines of echinids, Jurassic? foraminifera) is reworked from Mesozoic sediments forming the border of the Rhine Graben between Heidelberg and Karlsruhe. However, no further investigations on this fauna were undertaken; for distribution of this fauna see Fig. 4.

\section{SYSTEMATIC DESCRIPTIONS}

The material examined and figured is kept in the micropalaeontological collections (collection GRIESSEMER) of the Geological Survey of Rheinland-Pfalz at Mainz, Germany. From Chara rhenara sp. nov. some isotypes have been given to the British Museum (Natural History), London.

Division Charophyta Migula, 1890

Class Charophyceae G. M. Smith, 1938

Order Charales Richard, 1815

Family Characeae Richard, 1815

Genus Chara Vaillant, 1719

Chara rhenana sp. nov.

(Pl. 1, figs 1-4)

1992 Chara n. sp. Schwarz \& Griessemer: 30, figs 11-12 
Derivation of name. Rhenanus (latin), adjectival to Rhenus = Rhine, on account of the species' occurrence in the Rhine Graben.

Diagnosis. A medium-sized Chara species related to Chara subcylindrica; characteristic is the combination of a relatively low number of convolutions and the periapically \pm not modified spiral cells.

Holotype. Specimen figured on Pl. 1, fig. 1; no. 6717/12/1.

Isotypes. 3 figured specimens, Pl. 1, figs 2-4; nos $6717 / 12 / 2,6717 / 12 / 3,6717 / 12 / 4$.

75 measured, completely preserved unfigured specimens used for preparing Fig. 2 (of those, 15 specimens are kept in the collections of the British Museum (Natural History), London under V.63725).

About 125 unmeasured, unfigured specimens with lost apical part (of these, 25 specimens are kept in the collections of the British Museum (Natural History), London under V.63726).

Type locality. Clay-pit 'Am Viehweg' (Ziegelwerke Bott-Eder $\mathrm{GmbH}$ ), near Malsch south of Heidelberg, sample 12 (Fig. 1c); survey sheet 6717 Waghäusel.

Type stratum. Lower Pechelbronn Formation, ?Upper Eocene/?Lower Oligocene.

Depository. Geologisches Landesamt Rheinland-Pfalz, Mainz (Collection GRIESSEMER).

Material. About 200 gyrogonites.

Description. Oval to elliptic gyrogonites, as a rule constantly narrowed towards the base; gyrogonites thus occasionally with a somewhat conical appearance. Apical pole in general slightly depressed or even conspicuously flattened, not domed equally, as in the case of many Chara species. In a great number of specimens $(70 \%)$ the apical centre has broken off, which is evidence for rather decreased thickness of the spiral cells in the apical periphery. Spiral cells usually slightly concave to almost flat, rarely markedly concave or even convex; in the apical region invariably concave. Intercellular ridges barely prominent, periapical constrictions not, or at most poorly, discernible; apical ends of spiral celis, however, distinctly widened. Basal pore mainly within a shallow basal crateriform depression.

Dimensions. The most frequent values are given in parentheses; Fig. 2:

Length: $440-650 \mu \mathrm{m}(475-600 \mu \mathrm{m})$

Width: $330-490 \mu \mathrm{m}(375-425 \mu \mathrm{m})$

Number of convolutions: 8-10 (8-9)

Width of spiral cells: $50-80 \mu \mathrm{m}(50-70 \mu \mathrm{m})$

Diameter of basal pore: $20-40 \mu \mathrm{m}(20-30 \mu \mathrm{m})$

Isopolarity index: 120-171 (125-145).

Differential characters. (a) The characteristics of the apical structure of Chara rhenana sp. nov. prove a close relationship to Chara subcylindrica, described by Reid \& Groves (1921) from the Lower Headon Beds. Being comparable to the latter species in length, the gyrogonites of Chara rhenana sp. nov. are nevertheless distinctively more voluminous (that means lower isopolarity values), moreover the number of convolutions is obviously lower. (b) The species Chara tornata, Ch. cylindrica and Ch. elongata, once grouped together under the generic name
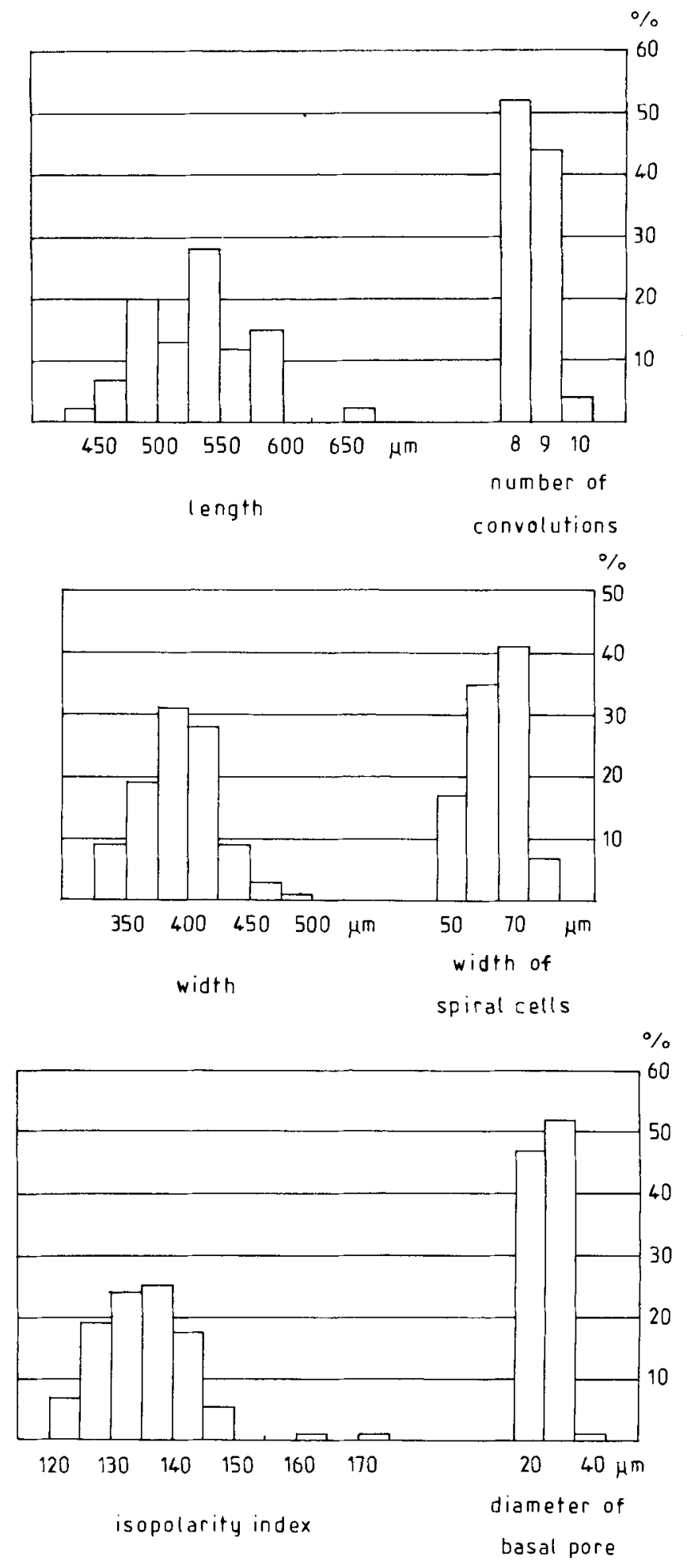

Fig. 2. Histograms of Chara rhenana sp. nov. $N=75$ gyrogonites.

Grambastichara, differ from the new species firstly by the noticeably periapically modified spiral cells, secondly by an \pm equally domed apex and thirdly by an elevated number of convolutions. 


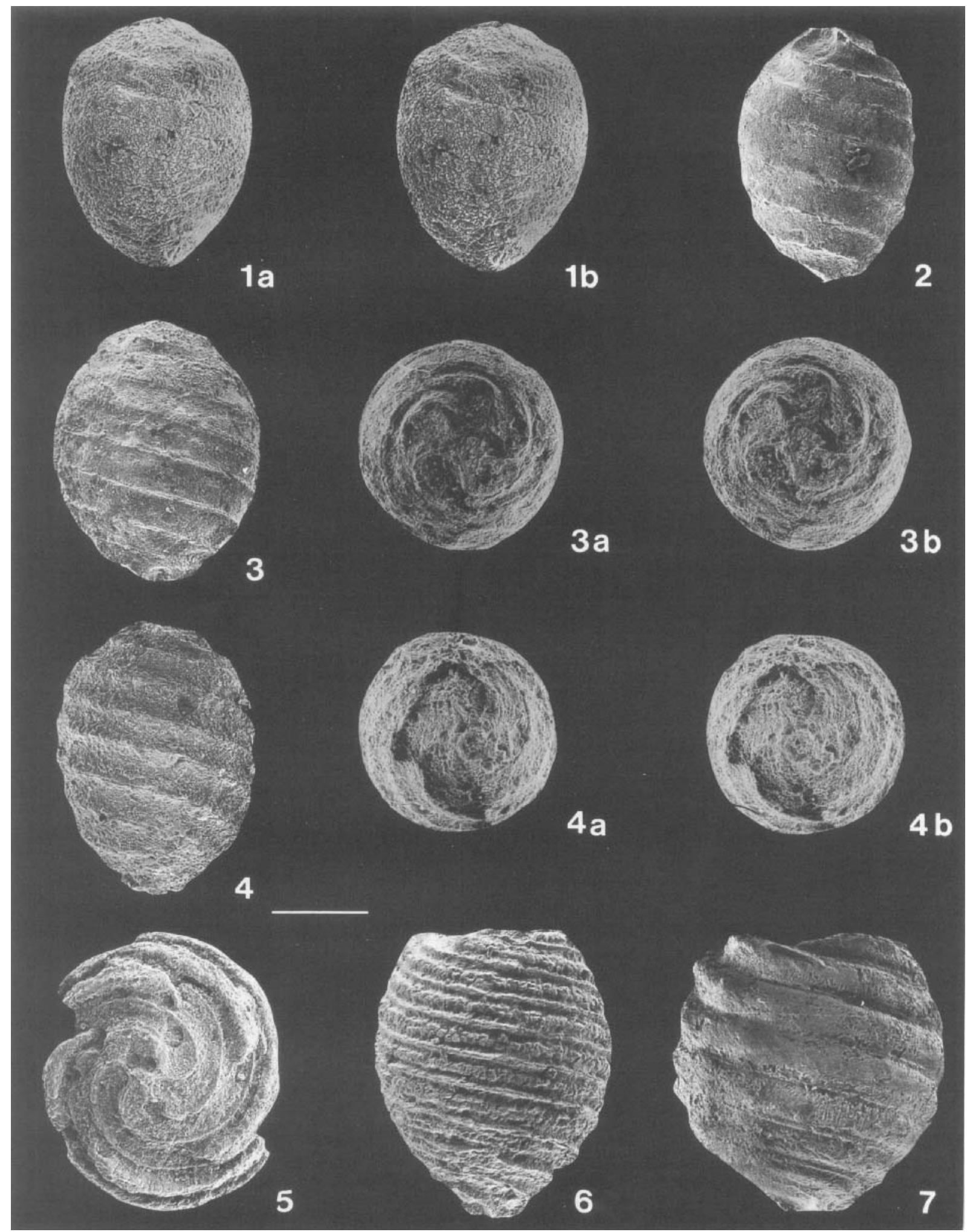

Plate 1 
Remarks. Riveline (1986: 68) points out the strong morphological similarities that exist between the genera Chara Vaillant, 1719 and Psilochara Grambast, 1959 from the Upper Eocene onwards and thus the difficulties which can arise in the generic assignment of some species; as an example she refers to Chara hamsteadensis. Likewise in Chara rhenana sp. nov., pecularities of both genera are combined: the oval, sometimes slightly conical shape of the gyrogonites points to the genus Chara, whereas the periapically, barely modified, spiral cells as well as the somewhat flattened apical region, are to be found within the genus Psilochara. A future revision of both genera would be highly desirable, especially since the diagnosis of Psilochara does not sufficiently separate that genus from Chara.

\section{Genus Harrisichara Grambast, 1957 \\ Harrisichara lineata Grambast, 1957}

(P1. 1, figs 5-6)

1957 Harrisichara lineata Grambast: 349, pl. 6, figs 5-7.

Brief description. Gyrogonites roundedly oval to elliptic. Apical region subtruncate, rarely slightly domed. Base always clearly prolonged into a short column. Spiral cells slightly concave, in the apical periphery barely narrowed but conspicuously reduced in thickness (Pl. 1, fig. 5). As a rule, with ornaments in form of a more or less distinct median band. The ornamentation ceases abruptly before the basal tips of the spiral cells. Basal pore at the bottom of an indistinct crateriform depression.

\section{Dimensions.}

Length: approximately 630-650 $\mu \mathrm{m}$; not exactly determined since not all the gyrogonites are preserved undamaged.

Width: $500-590 \mu \mathrm{m}$

Number of convolutions: $9-10$

Width of spiral cells: $70-90 \mu \mathrm{m}$

Diameter of basal pore: $20-30 \mu \mathrm{m}$.

Material. 8 fragmentary gyrogonites and debris respectively.

Genus Sphaerochara Mädler, 1952, emend. Horn af Rantzien \& Grambast, 1962

Sphaerochara parvula (Reid \& Groves, 1921) Horn af Rantzien, 1959

(Pl. 2, figs 4-5)

1921 Tolypella parvula Reid \& Groves: 188, pl. 6, figs 4-5. 1959 Sphaerochara parvula (Reid \& Groves); Horn af Rantzien: 136, pl. 16, figs 10-13.

1986 Sphaerochara parvula (Reid \& Groves); Breuer \& Feist: 142 , figs 3, 8 .
1992 Sphaerochara parvula (Reid \& Groves); Schwarz \& Griessemer: 32, fig. 18.

Brief description. Elliptical gyrogonites with rounded apical and basal poles. Spiral cells concave with distinct intercellular ridges, not modified in the apical periphery.

\section{Dimensions.}

Length: $350-380 \mu \mathrm{m}$

Width: $280-310 \mu \mathrm{m}$

Number of convolutions: $8-9$

Width of spiral cells: $40 \mu \mathrm{m}$

Diameter of basal pore: $20-30 \mu \mathrm{m}$

Isopolarity index: $112-125$

Material. 6 gyrogonites.

\section{Sphaerochara pygmaea Schwarz \& Griessemer, 1992} (Pl. 2, figs 1-3)

1992 Sphaerochara pygmaea Schwarz \& Griessemer: 34, figs 4, 13-17.

Brief description. Roundedly oval to elliptic gyrogonites with apex and base generally well rounded; the basal region may be prolonged sometimes (e.g. specimens from sample 2; Pl. 2, fig. 3). Spiral cells concave to a varying degree, their width rarely reduced in the apical region. Basal pore fairly wide, superficial. Basal plug visible from the exterior.

Dimensions.

Length: $240-340 \mu \mathrm{m}$

Width: $180-280 \mu \mathrm{m}$

Number of convolutions: $8-10$

Width of spiral cells: $20-40 \mu \mathrm{m}$

Diameter of basal pore: $20-40 \mu \mathrm{m}$

Isopolarity index: 109-150

Material. 64 gyrogonites.

Genus Nitellopsis Hy, 1889

Nitellopsis (Tectochara) cf. wonnacotti (Grambast, 1972) Grambast \& Soulié-Märsche, 1972

$$
\text { (Pl. 1, fig. 7) }
$$

1972 Tectochara wonnacotti Grambast: 22, fig. 9, pl. 7, figs $1-4$.

1972 Nitellopsis (Tectochara) wonnacotti (Grambast); Grambast \& Soulié-Märsche: 11.

The morphological features of this extremely rarely encountered species (one gyrogonite without apex, one apical fragment) are: gyrogonite of rounded shape; basal region largely rounded, not protruding; rather few convolutions (9). In spite of the somewhat low dimensions (length $c .920 \mu \mathrm{m}$, width $c .860 \mu \mathrm{m}$ ) the above-mentioned

\section{Explanation of Plate 1}

Scale bar for Figs $1-6=200 \mu \mathrm{m}$; for Fig. $7=300 \mu \mathrm{m}$. All specimens are from the Lower Pechelbronn Formation from the clay-pit 'Am Viehweg'. They are deposited in the micropalaeontological collections (collection GRIESSEMER) of the Geological Survey of RheinlandPfalz at Mainz. Figs 1-4. Chara rhenana sp. nov.; sample 12: figs 1a, b, holotype, no. 6717/12/1, lateral view, stereo pair; fig. 2 , specimen no. $6717 / 12 / 2$, lateral view; fig. 3 specimen no. 6717/12/3, lateral view figs 3a, b, same gyrogonite, apical view, stereo pair; fig. 4 specimen no. $6717 / 12 / 4$, lateral view figs $4 \mathrm{a}, \mathrm{b}$, same gyrogonite, basal view, stereo pair. Figs 5-6. Harrisichara lineata Grambast, 1957; sample 4: fig. 5, isolated apical portion of a gyrogonite (specimen no. 6717/4/2); the relief of the spiral cells ceases abruptly in the apical periphery, thus resulting in typical thinness of the apical centre; fig. 6, specimen no. 6717/4/1, lateral view, apical centre is broken off. Fig. 7. Nitellopsis (Tectochara) cf. wonnacotti (Grambast, 1972) Grambast \& Soulié-Märsche, 1972; sample 4; specimen no. 6717/4/4, lateral view of a gyrogonite lacking apical centre. 

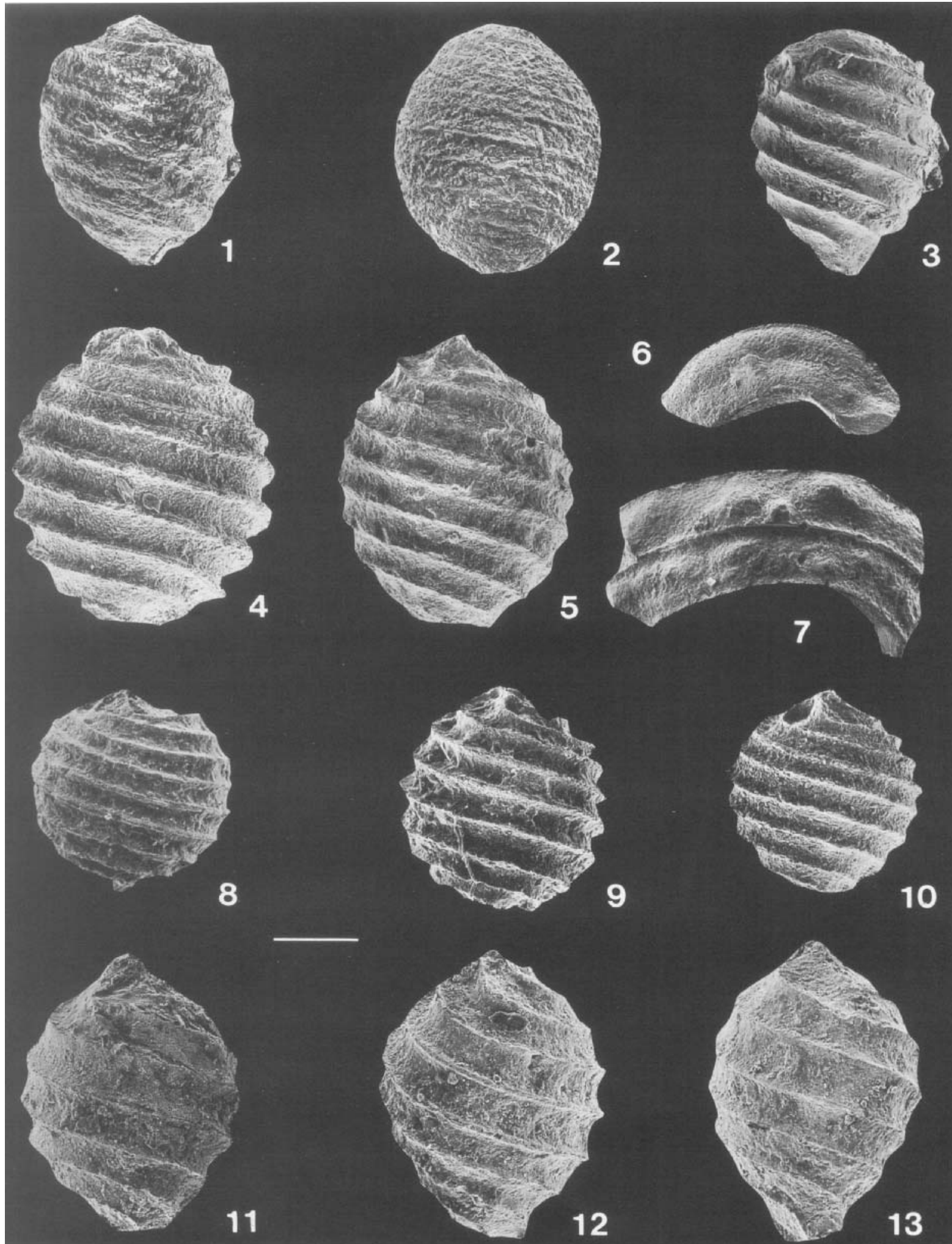

Plate 2 
characters clearly indicate a close relation to Nitellopsis wonnacotti and not to the species complex around Nitellopsis meriani.

Genus Gyrogona Lamarck, 1804 ex Lamarck, 1822, emend. Grambast, 1956

Gyrogona sp.

(Pl. 2, figs 6-7)

Samples 4 and 10 yielded some isolated and fragmentary, flat to barely concave spiral cells of great width (up to $170 \mu \mathrm{m})$ and thickness. Such cells are characteristic of the genus Gyrogona. Specific assignments on the basis of spiral cells alone are, of course, always delicate, but it may be presumed with some certainty that they belong to Gyrogona wrighti.

Genus Tolypella Braun, 1849

Tolypella pumila Grambast, 1958

(Pl. 2, figs 8-10)

1958 Tolypella pumila Grambast: 198, figs 1-3.

1992 Tolypella pumila Grambast; Schwarz \& Griessemer: 35, figs 19-20.

Brief description. Minute, globular gyrogonites; apex centrally pointed, base rounded. Spiral cells few, slightly concave, without any periapical modifications.

\section{Dimensions.}

Length: $240-340 \mu \mathrm{m}$

Width: $200-260 \mu \mathrm{m}$

Number of convolutions: $6-8$

Width of spiral cells: $30-40 \mu \mathrm{m}$

Diameter of basal pore: $20-30 \mu \mathrm{m}$

Isopolarity index: 102-125.

Remarks. Some of the gyrogonites originating from samples 5, 6 and 9 differ by having markedly concave spiral cells with strongly accentuated intercellular ridges.

Material. 23 gyrogonites.

Tolypella caudata Grambast, 1958

(Pl. 2, figs 11-13)

1958 Tolypella caudata Grambast: 199, figs 1-2.

1986 Tolypella caudata Grambast; Breuer \& Feist: 142, figs $3,9-10$.

Brief description. Gyrogonites broadly globular to roundedly oval. Apex with shortly pointed centre, in some specimens more protruding. Base gradually tapering, sometimes even distinctly prolonged. Basal pore quite small, superficial. Spiral cells slightly concave to flat, united in the apical region without any modifications with regard to their width; intercellular ridges hardly discernible.

Dimensions. (Fig. 3):

Length: $280-390 \mu \mathrm{m}(325-375 \mu \mathrm{m})$

Width: $240-310 \mu \mathrm{m}(250-300 \mu \mathrm{m})$

Number of convolutions: 6-9 (7-8)

Width of spiral cells: $30-60 \mu \mathrm{m}(40-50 \mu \mathrm{m})$

Diameter of basal pore: $20-30 \mu \mathrm{m}$

Isopolarity index: 104-145 (110-140)

Material. 70 gyrogonites.

\section{BIOSTRATIGRAPHY}

The charophyte association from the Lower Pechelbronn Formation of Malsch comprises exclusively those species that also exist at other ?Upper Eocene/?Lower Oligocene localities in the Rhine Graben system (Schwarz, in prep.).

Decisive for the biostratigraphic position of the locality Malsch/'Am Viehweg' is the synoptic representation of the hitherto known maximum vertical extension of all involved taxa.

- Chara rhenana sp. nov. appears in the Rhine Graben from the Lymnaea Marls up to the Upper Pechelbronn Formation (Schwarz \& Griessemer, 1992) with increased density records from the Lower Pechelbronn Formation (Table 1).

- Harrisichara lineata is confined, in the Rhine valley, to the Lymnaea Marls and the Lower Pechelbronn Formation (pers. obs.). To date, this species has been described only from western Europe (Riveline, 1986); there, its stratigraphic levels extend from the 'Marinésien moyen' (Chara friteli zone) to the 'Ludien moyen récent à supérieur' (Stephanochara vectensis zone).

- Sphaerochara parvula exists in the Rhine Graben area from the Lymnaea Marls (including the Green Marls Formation) to the Upper Pechelbronn Formation (Breuer \& Feist, 1986; Schwarz \& Griessemer, 1992). Its total vertical extension in western Europe covers all the interval between the 'Ludien inférieur' (Gyrogona tuberosa zone) and the 'Oligocène supérieur' (Chara notata zone) (Riveline, 1986).

- Sphaerochara pygmaea, a less frequently observed species, occurs in the Rhine Graben from the Lymnaea Marls up to the Upper Pechelbronn Formation (Schwarz \& Griessemer, 1992).

- Nitellopsis (Tectochara) cf. wonnacotti: a very few gyrogonites which are referable to this species have been

\section{Explanation of Plate 2}

Scale bar for Figs $1-5,8-13=100 \mu \mathrm{m}$; for Figs $6,7=200 \mu \mathrm{m}$. All specimens are from the Lower Pechelbronn Formation from the clay-pit 'Am Viehweg'. They are deposited in the micropalaeontological collections (collection GRIESSEMER) of the Geological Survey of Rheinland-Pfalz at Mainz. Figs 1-3. Sphaerochara pygmaea Schwarz \& Griessemer, 1992: fig. 1, specimen no. 6717/4/5, lateral view; sample 4; fig. 2, specimen no. 6717/4/6, lateral view, apical region well rounded; sample 4; fig. 3, specimen no. 6717/2/1, lateral view, basal region extraordinarily prolonged; sample 2. Figs 4-5. Sphaerochara paruula (Reid \& Groves, 1921) Horn af Rantzien, 1959: fig. 4, specimen no. 6717/4/3, lateral view; sample 4; fig. 5, specimen no. 6717/11/1, lateral view; sample 11. Figs 6-7. Isolated spiral cells of Gyrogona sp.; sample 4: fig. 6, specimen no. $6717 / 4 / 8$, basal end of spiral cell; fig. 7 , specimen no. $6717 / 4 / 7$, spiral cells from the equatorial region of a gyrogonite. Figs 8-10. Tolypella pumila Grambast, 1958: fig. 8, specimen no. 6717/9/1, lateral view; sample 9; fig. 9, specimen no. 6717/5/1, lateral view; sample 5; fig. 10, specimen no. 6717/6/1, lateral view; sample 6. Figs 11-13. Tolypella caudata Grambast, 1958; sample 9: fig. 11, specimen no. $6717 / 9 / 2$, lateral view; fig. 12 , specimen no. 6717/9/3, lateral view; fig. 13 , specimen no. $6717 / 9 / 4$, lateral view. 

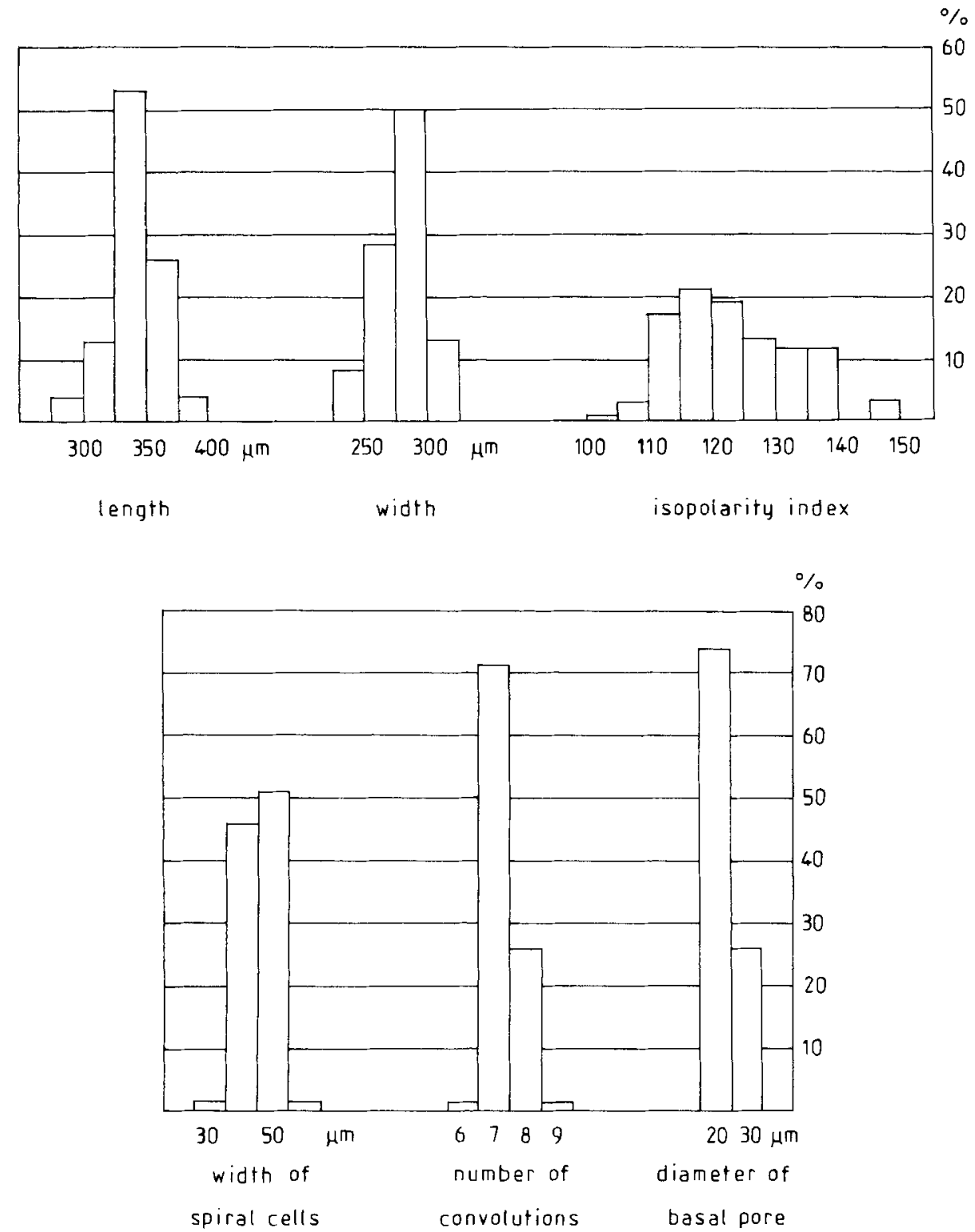

Fig. 3. Histograms of Tolypella caudata Grambast, 1958. $N=70$ gyrogonites.

found in two more localities of the Rhine Graben: the wells Winden 4 and Lautersheim 1. Their exact stratigraphic position has yet to be clarified absolutely. From the samples in question only the charophytes have been studied to date; they indicate with certainty an ?Upper Eocene/?Lower Oligocene age.

Apart from this, $N$. wonnacotti has been described only from the west European Hampshire and Paris Basins. There it characterizes lithological units which are to be placed within the Stephanochara vectensis zone ('Ludien moyen récent et/ou supérieur') (Riveline, 1986).

- Gyrogona sp.: possibly, the present fragmentary spiral cells may belong to Gyrogona wrighti, a species with a vast vertical extension - 'Auversien supérieur' (Raskyella pecki zone) up to 'Stampien inférieur de faciès sannoisien' (Stephenochara pinguis zone) - according to Riveline (1986).
- Tolypella pumila is a quite rarely encountered species in the Rhine Graben, which occurs from the Lymnaea Marls to the Upper Pechelbronn Formation (Schwarz \& Griessemer, 1992). In the Paris Basin it has been recorded from several localities in the Marnes bleues d'Argenteuil and the Calcaire de Brie (Cavelier et al., 1972; Riveline, 1973).

- Tolypella caudata has been quoted from the Lymnaea Marls of the Rhine Graben by Breuer \& Feist (1986). Originally, this species was described from the 'Tongrian' of Hoogbutsel (Belgium), but it also exists in the Paris Basin (Cavelier et al., 1972; Riveline, 1973). In western Europe, $T$. caudata is, like $T$. pumila, typical for deposits belonging to the Stephanochara vectensis and St. pinguis zones.

By reason of too great a vertical extension, most of the species at hand are, as a result, of no particular significance 


\begin{tabular}{|c|c|c|c|c|c|}
\hline $\begin{array}{l}\text { Stratigraphy } \\
\text { Rhine Graben }\end{array}$ & $\begin{array}{c}\text { Mammalian } \\
\text { levels }\end{array}$ & & $\begin{array}{l}\text { ratigraphy } \\
\text { pshire Basin }\end{array}$ & $\begin{array}{l}\text { Charophyte } \\
\text { zonation }\end{array}$ & $\begin{array}{l}\text { Stratigraphy } \\
\text { Paris Basin }\end{array}$ \\
\hline $\begin{array}{c}\text { Upper } \\
\text { Pechelbronn } \\
\text { Formation }\end{array}$ & \multicolumn{2}{|c|}{ Grande Coupure } & $\begin{array}{c}\text { Lower } \\
\text { Hamstead } \\
\text { Beds }\end{array}$ & $\begin{array}{c}\text { Stephanochara } \\
\text { pinguis } \\
\text { zone }\end{array}$ & $\begin{array}{l}\text { Argile verte } \\
\text { de Romainville }\end{array}$ \\
\hline $\begin{array}{l}\text { Middle } \\
\text { Pechelbronn } \\
\text { Formation }\end{array}$ & \multirow{2}{*}{ MP 20} & \multirow{3}{*}{$\begin{array}{c}n \\
\stackrel{d}{d} \\
\infty\end{array}$} & Bembridge & \multirow{3}{*}{ Stephanochara } & \multirow{2}{*}{ 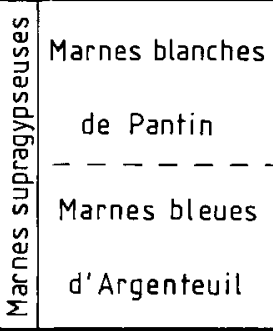 } \\
\hline $\begin{array}{l}\text { Lower } \\
\text { Pechelbronn } \\
\text { Formation }\end{array}$ & & & Marls & & \\
\hline $\begin{array}{l}\text { Lymnaea } \\
\text { Marls }\end{array}$ & MP 19 & & $\begin{array}{l}\text { Bembridge } \\
\text { Limestone }\end{array}$ & & $\begin{array}{c}\text { Première Masse } \\
\text { du Gypse }\end{array}$ \\
\hline
\end{tabular}

Table 1. Correlation table for the ?Upper Eocene/Lower Oligocene sequences of the Rhine Graben and the Hampshire and Paris Basins on the basis of charophyte and mammalian data.

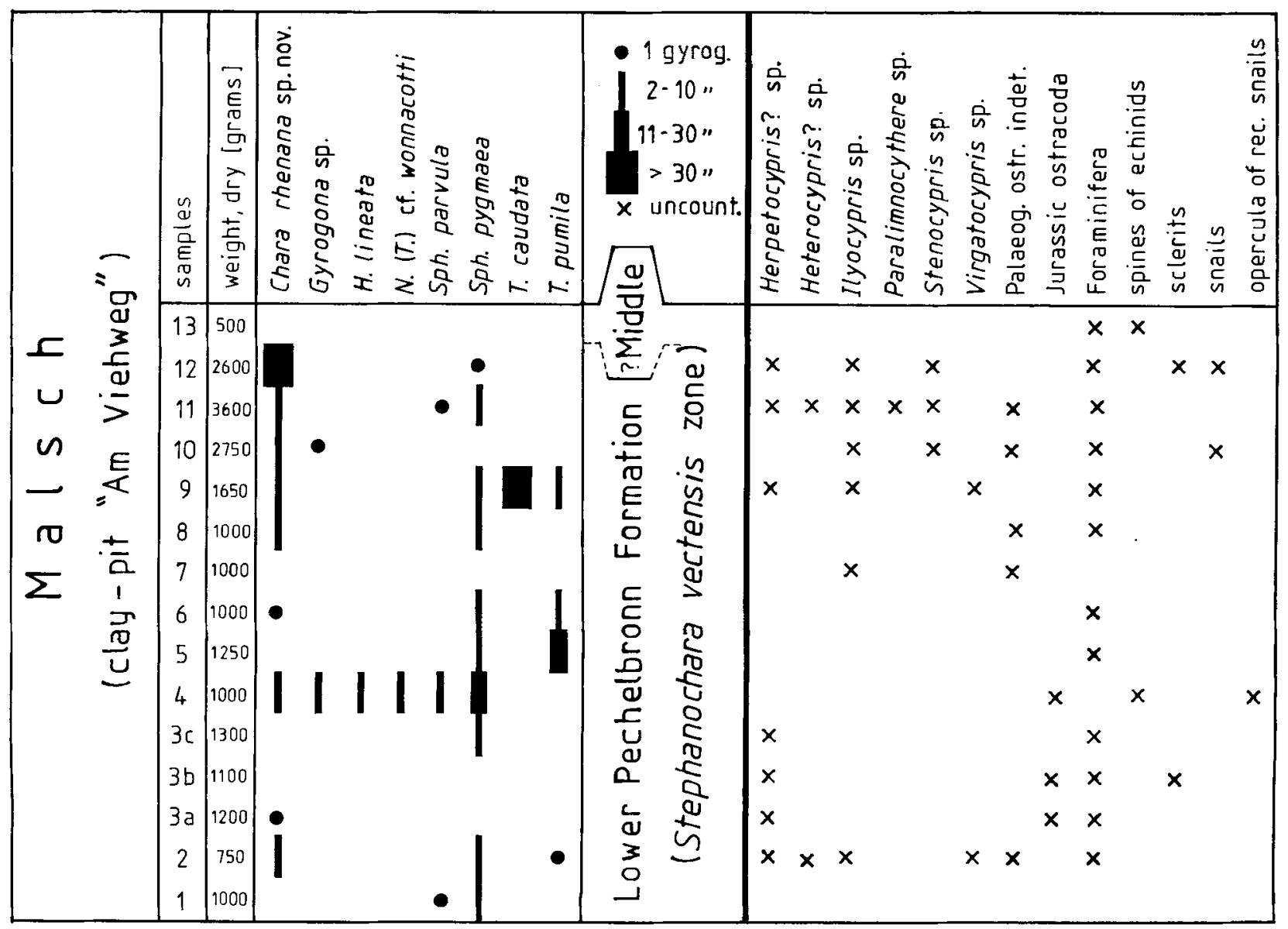

Fig. 4. Distribution of the charophyte species and associated fauna in the Lower Pechelbronn Formation of Malsch (clay-pit 'Am Viehweg'). 
for the biostratigraphic interpretation of the sedimentary sequence studied here. The possibility of a more circumscribed correlation is offered solely by the two 'exotics' of the assemblage, Harrisichara lineata and Nitellopsis (Tectochara) cf. wonnacotti, occurring together in sample 4 (Fig. 4): Stephanochara vectensis zone (Riveline, 1986).

In the Hampshire Basin the Stephanochara vectensis zone covers the whole series of the Bembridge Beds (Bembridge Limestone and Bembridge Marls); in the Paris Basin it is represented by the Première Masse du Gypse and the Marnes supragypseuses (Riveline, 1986).

It may be deduced easily that within the charophyte zonation the Lower Pechelbronn Formation parallels the lower parts of both the Bembridge Marls and the Marnes supragypseuses (i.e. the Marnes bleues d'Argenteuil). This concept, although in contrast to the opinion of Breuer \& Feist (1986; Table 1) in some aspects, would take into consideration equally well all data available for the mammal zonation; these data indicate concordantly an MP 20-age (reference locality: St. Capraise) for the following lithological units (Table 1):

- Lower Pechelbronn Formation: Tobien $(1987,1988)$.

- Bembridge Marls: Bosma (1974), Gad et al. (1990), Schmidt-Kittler (1987).

- Marnes bleues d'Argenteuil: Russell (1982).

\section{ACKNOWLEDGEMENTS}

We are gratefully indebted to the following persons and institutions who were involved in the present investigation: Prof. Dr K. Rothausen (Institut für Geowissenschaften, Paläontologie, University of Mainz) and Prof. Dr V. Sonne (Head of Geologisches Landesamt Rheinland-Pfalz, Mainz) who read the manuscript critically and suggested important improvements; the Ziegelwerke Bott-Eder GmbH, Rauenberg, who kindly gave us permission to take the samples from the clay-pit 'Am Viehweg'; the anonymous referee who greatly improved the text linguistically; the 'Deutsche Forschungsgemeinschaft' (Bonn) who generously supported the research financially with grants. The arrangement of the authors' names is accidental and no seniority is implied.

\section{Manuscript received November 1992 Manuscript accepted March 1994}

\section{REFERENCES}

Barth, S. 1970a. Stratigraphie und Tektonik der Tertiärscholle von Rot-Malsch im Rheingraben. Jahresberichte und Mitteilungen des Oberrheinischen Geologischen Vereins, Neue Folge Stuttgart, 52: 71-95.

Barth, S. 1970b. Feinstratigraphische und lithofazielle Untersuchungen der Pechelbronner Schichten von Rot-Malsch (Obereozän/Unteroligozän des Rheingrabens). Oberrheinische geologische Abhandlungen, Karlsruhe, 19: 43-60.

Bosma, A. A. 1974. Rodent biostratigraphy of the EoceneOligocene transitional strata of the Isle of Wight. Utrecht micropaleontological Bulletin Special Publications, Utrecht, 1.

Breuer, R. \& Feist, M. 1986. Biostratigraphisch bedeutsame Charophyten aus dem Alttertiär von Erdölfeldern des Oberrheingrabens. Newsletters on Stratigraphy, Berlin, Stuttgart, 16(3): 139-147.
Cavelier, C., Perreau, M., Riveline, J. \& Turland, M. 1972. Contribution paléontologique (Characées et Mollusques) à la stratigraphie détaillée du Marinésien, du Ludien et du Stampien inférieur dans la région de Montereau (Seine-et-Marne). Bulletin d'Informations des Geologues du Bassin de Paris, Paris, 34: $31-42$.

Gad, J., Martini, E., Rothausen, K. \& Tobien, H. 1990. Theridomys pseudosiderolithicus (Rodentia, Mammalia) aus den unteroligozänen Vorkommen von Bodenheim bei Mainz (Mainzer Becken), Neustadt, Kreis Marburg (Hessische Senke), der Isle of Wight (Hampshire Becken) und deren Beziehungen zur marinen Standard-Biostratigraphie. Mainzer geowissenschaftliche Mitteilungen, Mainz, 19: 163-182.

Grambast, L. 1959. Extension chronologique des genres chez les Charoideae. Société des Editions Technip 1959, Paris, 1-12.

Keen, M. C. 1975. The palaeobiology of some upper Paleogene freshwater ostracodes. Bulletins of American Paleontology, Ithaca/NY, 65(282): 271-283.

Moos, A. 1934. Die Erdölbohrungen im nördlichen Rheintalgraben bei Bruchsal 1921-1926. Schriften aus dem Gebiet der Brennstof-Geologie, Stuttgart, 9 Heft: Deutsches Erdöl II. Folge $12-76$.

Morkhoven, F. P. C. M. van. 1963. Post-palaeozoic ostracoda. Their morphology, taxonomy, and economic use. Vol. II: Generic descriptions. Elsevier, Amsterdam, London, New York.

Reid, C. \& Groves, J. 1921. The Charophyta of the Lower Headon Beds of Hordle (Hordwell) Cliffs (South Hampshire). Quarterly Journal of the Geological Society of London, London, 77: 175-192.

Riveline, J. 1973. Répartition des Characées dans les calcaires lacustres de l'Eocène terminal et de l'Oligocène basal du Sud-Est du Bassin de Paris. Comptes rendus hebdomadaires des Séances de l'Academie des Sciences Paris, série D, Paris, 277: 2641-2643.

Riveline, J. 1986. Les Charophytes du Paléogène et du Miocène inférieur d'Europe occidentale. Biostratigraphie des formations continentales. Cahiers de Paléontologie, Editions CNRS, Paris.

Russell, D. E. (ed.) 1982. Tetrapods, of the Northwest European Tertiary Basin. International Geological Correlation Programme Project 124: The Northwest European Tertiary Basin. Geologisches Jahrbuch, Hanover, A60: 5-74.

Schmidt-Kittler, N. (ed.) 1987. International Symposium on Mammalian Biostratigraphy and Palaeoecology of the European Paleogene - Mainz, February 18th-21st 1987. Münchner Geowissenschaftliche Abhandlungen, Munich, (A)10.

Schwarz, J. \& Griessemer, Th. W. 1992. CharophytenMassenvorkommen aus den Oberen Pechelbronn-Schichten (Unteroligozän) von Merkwiller-Pechelbronn im Elsaß (Dépt. Bas-Rhin, Frankreich). Paläontologische Zeitschrift, Stuttgart, 66(1/2): 23-37.

Tobien, H. 1949. Säugetierpaläontologische Daten zur Altersbestimmung des tieferen Tertiärs im Rheintalgraben. Berichte der naturforschenden Gesellschaft zu Freiburg im Breisgau, Freiburg i. Br., 39: 17-52.

Tobien, H. 1968. Mammifères éocènes du Bassin de Mayence et de la partie orientale du Fossé rhénan. Mémoires du B.R.G.M., Paris, 58: Coll. sur l'Eocène, Paris, mai 1968: 297-307.

Tobien, H. 1987. The Position of the 'Grande Coupure' in the Paleogene of the Upper Rhine Graben and the Mainz Basin. In Schmidt-Kittler, N. (ed.), International Symposium on Mammalian Biostratigraphy and Palaeoecology of the European Paleogene. Muinchner Geowissenschaftliche Abhandlungen, Munich, (A)10: 197-201.

Tobien, H. 1988. 4.8.2.2.3. France-The Federal Republic of Germany: The Rhine Graben and the Mainz Basin. In Vinken, R. (ed.), The Northwest European Tertiary Basin, Results of the IGCP No 124. Geologisches Jahrbuch, Hanover, A100: 395-398.

Triebel, E. 1953. Genotypus und Schalen-Merkmale der Ostracoden-Gattung Stenocypris. Senckenbergiana, Frankfurt am Main, 34(1/3): 5-14.

Wilser, B. 1922. Cyrenenmergel (?) bei Rot-Malsch (Baden). Jahresberichte und Mitteilungen des Oberrheinischen Geologischen Vereins Neue Folge Stuttgart, 11: 16-22. 